ETO: $81 ’ 246.2-053.2$

ORIGINAL SCIENTIFIC PAPER

81 '232

159.922 .7

DOI: $10.19090 / h k .2019 .4 .36-48$

\title{
BARTHA Krisztina
}

Partiumi Keresztény Egyetem, Bölcsészettudományi Kar

Nyelv- és Irodalomtudományi Tanszék

Nagyvárad, Románia

krisztinabartha83@gmail.com

\section{ÉLETKORI SAJÁTOSSÁGOK A MOORE-PARADOXONOS MONDATOK MEGÉRTÉSÉBEN KÉTNYELVÜ GYERMEKEKNÉL}

\section{Age-Differences in Understanding Moore-Paradox Sentences by Bilingual Children}

\author{
Uzrastne karakteristike u razumevanju \\ „Mur-paradoksalnih rečenica” kod dvojezične dece
}

A kétnyelvü gyermekek számos kognitív és végrehajtó funkció müködtetésében mutatnak előnyt az egynyelvüekhez képest. Kutatásomban a tudatelmélet fejlődéséhez kapcsolódó képességet vizsgálom kétnyelvű gyermekeknél: a Moore-paradoxonos mondatok megértésének sajátosságait. Ezeket az eredményeket összevetem a szintaktikai tudatosság kompetenciájának fejlődésével. Kutatásom célja, hogy megismerjem a kétnyelvü gyermekek ezen képességeinek jellemzőit, kialakulásuk időpontját, megfigyeljem, hogy mutatnak-e összefüggést egymással. Kérdéseim: Mikor alakul ki a logikai ellentmondást tartalmazó mondatok megértése kétnyelvü gyermekeknél? Hatással van-e a kétnyelvűség típusa a megértés fejlödésére? Összefügg-e a szintaktikai tudatosság képessége és a Moore-paradoxonos mondatok megértése? Kísérletemben nyolcvan szimultán és szukcesszív kétnyelvű 5-8 éves gyermek vett részt. Eredményeim igazolják, hogy a szimultán kétnyelvü gyermekek gyorsabban fejlődnek a szukcesszív kétnyelvüeknél.

Kulcsszavak: szimultán és szukcesszív kétnyelvűség, Moore-paradoxon, szintaktikai tudatosság 


\section{Bevezetés}

A tudatelmélet vizsgálata a megismeréstudományokban, a fejlődéslélektani, pszicholingvisztikai és kísérleti filozófiai kutatásokban is régóta központi téma. A naiv tudatelmélet kifejezésnek több szinonimája is van: népi pszichológia, mentalizáció, mindennapi pszichológia, elmeteória stb. (Kiss 2015). A tudatelméleti jelenségek tehát a hétköznapi pszichológiát foglalják magukban, ami arra a képességünkre utal, hogy magunkat és másokat mentális állapotok összegeként látjuk, azaz felismerjük a vágyakat, érzelmeket, szándékokat és egyéb belső állapotokat, amelyek viselkedésekben nyilvánulnak meg (WellmanCross-Watson 2001). Ezeknek a tényezőknek a felismerése és tudatos kezelésük elengedhetetlen a társas kapcsolatokban, de ugyanilyen jelentőséggel bír annak a képességnek a kialakulása, ami által az egyén képes felismerni, hogy a társas közegben a többieknek is vannak mentális állapotaik, vágyaik és céljaik, amelyek az ő viselkedéseiknek alapjában állnak. A tudatelméletről ma már sokan úgy vélekednek, hogy velünk született és univerzális képesség, ami nélkül a társadalomban képtelenek lennénk müködni, nem tanult, hanem elsajátított képesség, hasonlóan a beszédhez vagy a járáshoz (Premack-Woodruff 1978; Wellman-Estes 1986). Az egyén akkor rendelkezik a tudatelmélet képességével, ha olyan mentális állapotokra vonatkozó fogalmakkal rendelkezik, mint a lát, hisz, tud, akar, emlékszik, vél, és ha az egyén arra is használja ezeket a fogalmakat, hogy mások viselkedését előrejelezze és magyarázza (Heyes 1998).

A vélekedések és ezek közül is a hamis vélekedések megértése a fejlődéspszichológia szempontjából azért fontos vizsgálódási terület, mert ezek többféle kognitív képességet is feltételeznek. A gyermeknek meg kell értenie, hogy a mentális állapotok leképezhetik a valóságot, de ettöl függetlenek is lehetnek és mindenképpen belső, mentális jelenségek. Az egyik legismertebb tudatelméleti kísérlet a hamisvélekedés-teszt, aminek a helyes megoldására körülbelül négyéves kortól képesek a gyermekek. Ez látszólag megkérdőjelezi a veleszületettség elméletét, ugyanakkor nem szabad elfeledkezni arról, hogy a hamis vélekedéses kísérletek helyes megoldásához előbb ki kell alakulnia a megosztott figyelmi mechanizmusnak (Baron-Cohen-Swettenham 1996), a gátló folyamatoknak (Carlson-Moses 2001) is jól kell müködniük, és a nyelvi és metanyelvi képességek fejlettségére (Farrar-Diaz 2017) is szükség van.

A hamisvélekedés-teszt első kísérleti jellegü vizsgálata Wimmer és Perner nevéhez fúződik (Kiss 2015). A hamisvélekedés-tesztek struktúrája szerint a gyermekeknek meg kell jósolniuk a kísérletben szereplő személy viselkedését az illető hamis vélekedése alapján, miközben saját helyes vélekedésüket figyel- 
men kívül kell hagyniuk. A klasszikus Wimmer és Perner (1983) kísérletben a kísérleti személy egy rövid történetet lát, amiben a főhős egy darab csokoládét tesz egy szekrénybe, majd távollétében az édesanyja ezt áthelyezi. A gyermekeknek azt a kérdést kell megválaszolniuk, hogy amikor a főhős visszatér, az első vagy a második helyen fogja-e keresni a csokoládét. A hároméveseknek a hamisvélekedés-tesztet nem sikerül helyesen megoldaniuk, de 4-6 éves társaiknak már igen, azaz ezek a gyermekek már képesek hamis vélekedést tulajdonítani a főhősnek (Wimmer-Perner 1983).

A tudatelméleti fejlődésben tehát kiemelt szerepe van a vélekedések megjelenésének és fejlődésének, a vélekedések tulajdonításának, majd a hamis vélekedések megértésének. A vélekedések voltaképpen olyan propozicionális attitüdök, amelyek két részből állnak, egy attitüdből és egy propozícióból. Például abban a mondatban, hogy Azt hiszem, hogy esik az eső, az első rész (azt hiszem) jelenti az attitüdöt, a második rész (esik az esö) a propozíciót. A vélekedés hasonló a többi mentális állapotunkhoz, ugyanakkor egy mentális reprezentáció is (Kiss 2017).

A Moore-paradoxonos mondatok gondolatban és beszédben egyaránt előforduló jelenségére Moore hívta fel a figyelmünket. Ezt a paradoxont leggyakrabban a következő példával szokták szemléltetni: Esik az esö, de nem hiszem, hogy esik az esö, ennek formulája pedig: $p$, és nem hiszem azt, hogy $p$ vagy $p$, és úgy vélem, hogy nem $p$, illetve a tudásra vonatkozóan: úgy vélem, hogy $p$, és nem tudom, hogy $p$. Ezeket a mondatokat azért tarthatjuk paradoxonoknak, mert nem mondhatók ki egyszerre anélkül, hogy ne hangoznának abszurdnak (Kiss 2017; Fileva-Brakel 2018). Ennek az oka az, hogy amikor az egyén egy propozíciót fogalmaz meg, abban implicit módon is benne van az adott propozícióról alkotott attitüdje, azaz ha egymás után mondja ki az esik az eső propozíciót, és a nem hiszem, hogy esik az eső propozicionális attitüdöt, akkor ellentmond önmagának (Rosenthal 1995; Green-Williams 2007). Ugyanezzel a logikával érvel Searle $(2009,41)$ is, aki szerint, amikor egy propozícióval állítunk valamit, az állítás maga egy elköteleződés is a propozíció igazsága mellett. A propozíciót tartalmazó illokúciós aktus kimondása által egy intencionális pszichológiai állapotot is kifejezünk. Ez a mentális állapot az őszinteségi feltétele a beszédaktusnak (Searle 1983, 9). A Moore-féle mondatok tehát szokatlanul hangzanak, mivel különösnek, abszurdnak tünik, ha valaki a beszédaktus során állít valamit, de közvetlenül ezt követően tagadja a hozzá kapcsolódó pszichológiai állapotot. Jelen tanulmányban nem térek ki a Moore-paradoxonos mondatok filozófiai megközelítéseire, a paradoxon és az abszurditás elméleteire, a célom csupán az, hogy megvizsgáljam a Moore-paradoxonos mondatok felismerését 
gyermekkorban az életkor és a kétnyelvüség függvényében, valamint hogy a kapott eredményeket összehasonlítsam a szintaktikai tudatosság fejlettségével.

A nyelvi tudatosság a nyelvhasználó azon képessége, hogy hozzáférjen a nyelvhez, ráirányítsa figyelmét, elemeire bontsa, és reflektáljon rá (Adamikné 2006). A nyelvi tudatosság mint kompetencia minden nyelvi szinten jelen van, így beszélünk fonológiai, morfológiai, lexikai-szemantikai, szintaktikai és pragmatikai tudatosságról is (Török-Hódi 2015). A szintaktikai tudatosság a grammatikai struktúrákhoz való tudatos hozzáférést, az ezekről való gondolkodást jelenti. A szintaktikai struktúrákhoz való hozzáférés komplex folyamatának vizsgálatát jellemzően a grammatikailag hibás alakok felismerésével végzik (Cromdal 1999; Davidson-Raschke-Pervez 2010; Galambos-Goldin-Meadow 1990; Galambos-Hakuta 1988). A vizsgálatok előnyt feltételeznek a kétnyelvü gyermekek esetében abból kiindulva, hogy a nyelvi fejlődés során ők azok, akik jellemzőbben ráirányítják a figyelmüket a nyelvi szerkezetekre amiatt, hogy a hatékony kommunikáció érdekében meg tudják állapítani, hogy egy bizonyos grammatikai szerkezet melyik nyelvhez tartozik, és hogyan hangzik helyesen (Davidson-Raschke-Pervez 2010). A pszicholingvisztikai kutatások kiemelik a kétnyelvűség egyéb előnyeit is a kognitív fejlődésben, ilyenek például a gátló mechanizmusok használata, rugalmasabb gondolkodás (Bialystok-Viswanathan 2009), figyelmi készségek (Bialystok-Feng 2009), és megállapítják, hogy a kétnyelvűek, főként gyermekkorban, jobban teljesítenek a nyelvi és a metanyelvi tudatossági kísérletekben (Bialystok 1991, 2006, 2011; Francis 2002).

\section{Célok, kutatási kérdések és hipotézis}

Kutatásom célja, hogy megismerjem a kétnyelvü gyermekek tudatelméleti képességeinek fejlődését, ezen belül a jelen tanulmányban azt vizsgálom, hogy mikor kezdődik a Moore-paradoxonos mondatok felismerése és megértése. Feltételezésem szerint a Moore-paradoxonos mondatokban lévő ellentét felismerését nyelvi képességek is befolyásolják. Ezek közül kiemelt jelentőséget tulajdonítok a szintaktikai tudatosság fejlettségének, így célom az is, hogy összevessem a szintaktikai tudatosságot vizsgáló teszten nyújtott eredményeket a Moore-paradoxonos kísérlet eredményeivel. Ugyanakkor a kétnyelvü gyermek nyelvi környezetének hatásait, kétnyelvüségük típusának jelentőségét is vizsgálom a tudatelmélet és a nyelvi tudatosság fentebb említett egységeire vonatkozóan. Kutatási kérdéseim a következők: Mikor alakul ki a logikai ellentmondást tartalmazó mondatok megértése kétnyelvü gyermekeknél? Kimutatható-e kapcsolat a szintaktikai tudatosság fejlettsége és a Moore- 
paradoxonos mondatok megértése között? Hatással van-e a kétnyelvüség típusa a megértés fejlődésére?

Hipotéziseim szerint: i) a szimultán nyelvelsajátítással rendelkező, vegyes családban élő kétnyelvü gyermekeknél hamarabb alakulnak ki a tudatelmélet jelenségei (jelen esetben a Moore-paradoxonos mondatok felismerése), mint a szukcesszív nyelvelsajátításban részesülő, egynyelvü családban élő gyermekeknél; ii) szoros összefüggés van a Moore-paradoxonos mondatok felismerése és a szintaktikai tudatosság fejlettsége között mindkét kétnyelvüségi csoportban.

\section{Adatközlök és kisérleti módszerek}

Kutatásomban nyolcvan magyar-román kétnyelvű gyermeket vizsgáltam. A gyermekek 5 és 8 éves kor közöttiek voltak, minden életkori csoportba 20 gyermek került, átlagéletkoruk 6 és fél év volt (medián 6,5 év). A nemek szerinti eloszlást tekintve 43 fiú és 37 lány vett részt a vizsgálatban. A gyermekek mindannyian városi óvodába vagy iskolába járnak, átlagos szociális háttérből származnak, ép hallásúak és ép intelligenciájúak.

A kétnyelvűségi csoportokba sorolást a szülői kérdőív alapján végeztem el, és ez alapján állapítottam meg a gyermekek nyelvismeretét is. A csoportba sorolás alatt két szempontot is figyelembe vettem. A szimultán kétnyelvüségi csoportba csak vegyes családból származó gyermekek kerültek, akik születésüktől kezdve mindkét nyelvet elsajátították. A másik szempont az ő esetükben, hogy mindkét nyelvüket jól ismerjék, és a nyelvi kompetenciáik alapján kiegyensúlyozott kétnyelvüeknek legyenek tekinthetők. A szukcesszív kétnyelvủek szintén korai életkorban kezdték megismerni mindkét nyelvet, de az ő esetükben szempont volt, hogy egynyelvü magyar családból származzanak, és a domináns nyelvük a magyar legyen. A románt ezek a gyermekek az óvodában életkoruktól függően 2-5 éve - tanulják, valamint a tágabb nyelvi környezetből is ismerhetik azt, hiszen a város, ahol a vizsgálatot végeztem, dominánsan románlakta település (a román anyanyelvűek aránya kb. 75\%-os).

A gyermekek nyelvi képességeit a szülők által kitöltött kérdőív segítségével határoztam meg (0-10 közötti pontozás). Ez azt tükrözi, hogy a szimultán kétnyelvü gyermekek magyar és román nyelvtudása valóban közel áll egymáshoz, a szülők átlagosan 9,2 pontot (medián 9, szórás 0,79 ) adtak a gyermekeik magyar nyelvtudására, és 8,8 pontot (medián 9, szórás 0,96) a románra (lásd 1. táblázat). A szukcesszív kétnyelvüséggel rendelkező csoportban a magyar nyelvtudásra a szülők 9,5 (medián 10 , szórás 0,67 ) pontot adtak, míg a román nyelvtudást átlagosan 3,7-re (medián 4, szórás 1,2) értékelték. A szukcesszív és 
a szimultán kétnyelvü csoportok között a magyar nyelvismeretben nincsenek statisztikailag kimutatható eltérések, a román tudás tekintetében a két csoport közötti eltérés szignifikáns: $\mathrm{t}(78)=20,584, \mathrm{p}<0,000$.

\begin{tabular}{|c|c|c|}
\hline $\begin{array}{c}\text { Kétnyelvüségi } \\
\text { csoportok }\end{array}$ & Magyarnyelv-tudás & Románnyelv-tudás \\
\hline \multirow{3}{*}{ Szimultán kétnyelvűek } & Átlag: 9,2 & Átlag: 8,8 \\
& Medián: 9,0 & Medián: 9,0 \\
& Szórás: 0,79 & Szórás: 0,96 \\
\hline Szukcesszív & Átlag: 9,5 & Átlag: 3,7 \\
kétnyelvüek & Medián: 10,0 & Medián: 4,0 \\
& Szórás: 0,67 & Szórás: 1,2 \\
\hline
\end{tabular}

Forrás: Saját táblázat

1. táblázat. A magyar és a román nyelvtudás a kétnyelvüségi csoportokban

A kísérletben Kiss Szabolcs (2017) anyagát használtam fel, melyben 25 Moore-paradoxonos mondat felismerését teszteltem. Ezekben a mondatokban az első és a második tagmondat ellentmondást tartalmazott, azaz a második részben olyan mentális állapotot fejez ki a beszélö, ami nem egyeztethető össze a mondat első részével: Esik a hó, de nem vélem úgy, hogy esik a hó. Fogócskázzunk, de nem akarok Veled játszani! A Moore-paradoxonos mondatokat szintaktikailag hasonló kontrollmondatokkal együtt használtuk fel. A gyermekeknek két beszélő közül kellett kiválasztaniuk azt a személyt, aki valami furcsát mond. Az egyik beszélő Moore-paradoxonos mondatot mondott, a másik pedig egy hozzá illesztett nem paradoxonos mondatot. Az Esik a hó, de nem vélem úgy, hogy esik a hó mondat párja: Esik a hó, de nem marad meg ebben az időben. A gyermekek a mondatokat hangfelvételröl hallgatták meg, a kísérletvezető instrukciója a következőképpen hangzott: Figyelj csak, valami érdekeset fogunk játszani! Mindjárt Katit és Petit fogod hallani beszélni, de az egyikük mindig valami furcsát, szokatlant mond. Hol az egyik, hol a másikfog furcsát mondani, és a Te feladatod az lesz, hogy válaszd ki, hogy kettejük közül éppen ki mondott valami szokatlant. Mindig nevezd meg, hogy ki mondott az imént valami furcsát! Az instrukciót követően két gyakorló mondatpárt hallgatott meg minden gyermek, ezt követte a tényleges tesztelés.

A szintaktikai tudatosság mérésére saját kísérleti anyagot alakítottam ki. Ennek lényege, hogy a kísérletvezető grammatikailag hibás és helyes mondatokat olvas fel a gyermekeknek a következő utasítás kíséretében: Most ismét valami érdekeset fogunk játszani. Mondani fogok neked valamit, te pedig el kell 
döntsd, hogy amit mondtam, az jó, értelmes volt, vagy furcsa, értelmetlen volt. Minden mondat meghallgatása után elhangzik a következő felszólítás: Mondd meg, hogy jó, értelmes, vagy furcsa, értelmetlen volt, amit mondtam! A teszt összesen 26 egyszerú mondatot tartalmaz, 13 grammatikailag helytelen és 13 helyes mondatot. A mondatok páronként ugyanazt a grammatikai problémát vetik fel, például $A$ ceruzák az asztalon van és $A$ tányér az asztalon van. A mondatpárok ez esetben nem egymás után, hanem keverve hangzanak el. A gyermekek feladata volt az is, hogy a hibás mondatokat kijavítsák, és hibátlanul mondják el azt. A javítási stratégiákra, eredményekre jelen tanulmányban nem térek ki.

Az adatok feldolgozását az SPSS 22.0 statisztikai programmal végeztem el, ahol százalékszámítást, Pearson-féle korrelációszámítást, ANOVA-tesztet és Tukey-féle post hoc tesztet, valamint független mintás t-próbát alkalmaztam.

\section{Eredmények}

A 25 mondatpár felismerésében az átlagos teljesítmény 18,1 (medián 17, szórás 4,9) mondat felismerése volt. Az életkorok szerint lényeges növekedést mutatnak a számadatok. A teljes csoportban az 5 évesek átlagban 13,4 mondatot ismertek fel, a 6 évesek 17,1-et, a 7 évesek 19,1-et, míg a 8 évesek 23,1et. Az egytényezős ANOVA-próba alapján kimutatható a különbség: $F(3,79)$ $=26,360 ; p=0,000$. A Tukey-féle post hoc teszt az 5 és 6 , az 5 és 7, valamint az 5 és 8 évesek csoportja között is erős, szignifikáns különbséget mutatott $(p<0,001)$, a 6 és a 8 évesek csoportja és a 7 és 8 évesek csoportja között is $(p<0,001)$ szintén erős szignifikáns különbség volt. Az életkori csoportokban a $80 \%$ feletti (20 vagy annál több helyesen felismert mondat) teljesítmény a következőképpen alakult: az 5 évesek mindössze 5\%-a (1 gyermek), a 6 évesek 15\%-a (3 gyermek), a 7 évesek 50\%-a (10 gyermek) és a 8 évesek 85\%-a (18 gyermek) ismerte fel a paradoxont.

A kétnyelvüségi csoportok eredményei alapján látható, hogy az életkori tendencia természetesen hasonló a teljes csoport adataihoz (lásd 1. ábra), de látható, hogy mindegyik életkori csoportban a szimultán kétnyelvü gyermekeknél magasabb, így 5 éves korban a szimultán kétnyelvüek 15 mondatot ismertek fel, a szukcesszív kétnyelvüek pedig 11,8-at, a 6 évesek 19,3-at a szimultán csoportban és 14,9-et a szukcesszívben. A 7 évesek átlaga a szimultán kétnyelvüeknél 22,7 jól felismert mondat, míg a szukcesszív gyermekeknél 15,6 mondat. Végül a 8 évesek közül a szimultán kétnyelvüséggel rendelkezők majdnem mindannyian az összes mondatot felismerték, így az átlaguk 23,9 mondat, a szukcesszívek esetében pedig 22,3 mondat. A független mintás 
t-próba alapján a két csoport teljesítménye között statisztikailag is kimutatható, erős szignifikáns különbség van: $\mathrm{t}(78)=4,029, \mathrm{p}<0,001$.

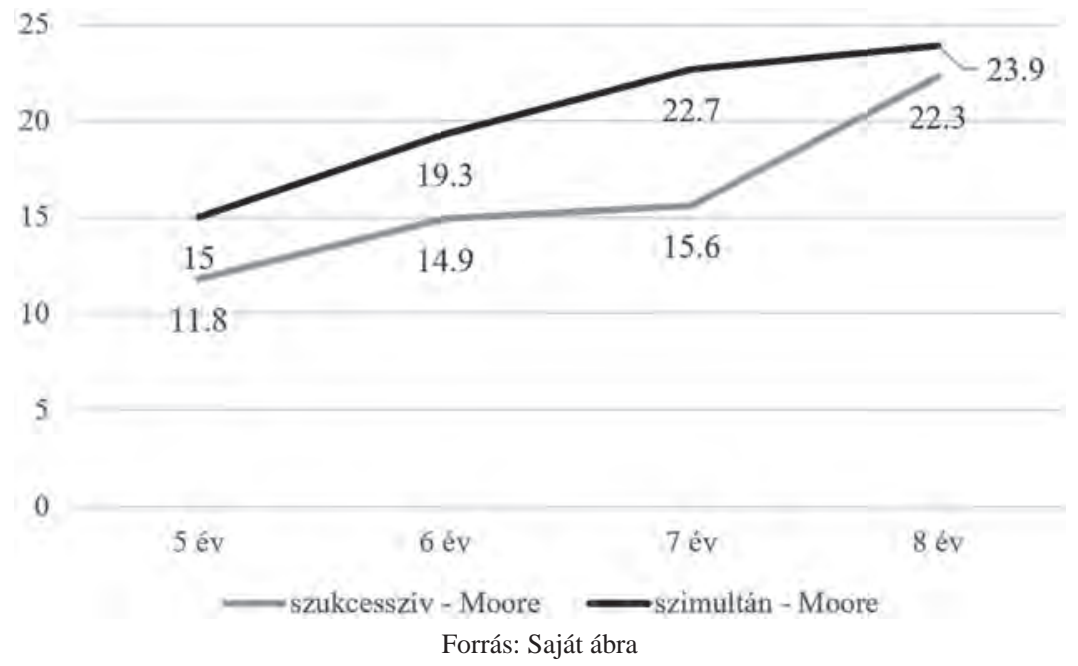

1. ábra. A Moore-paradoxonos mondatok felismerése a kétnyelvüségi csoportokban életkori bontás szerint

$80 \%$ fölötti teljesítménnyel a szukcesszív nyelvelsajátítással rendelkező csoportban az 5 és a 6 éveseknél nem találkozunk. A 7 évesek esetében a csoport 10\%-a (1 gyermek), míg a 8 évesek $80 \%$-a (8 gyermek) tudta 20 -nál több esetben helyesen kiválasztani az abszurd mondatot. A szimultán kétnyelvü gyermekek eredményei jobbak: az 5 évesek csoportjában 10\% (1 gyermek), a 6 éveseknél 30\% (3 gyermek), a 7 évesek esetében 90\% (9 gyermek), míg a 8 éveseknél minden gyermek, azaz 100\%-uk ismerte fel a mondatok 80\%-át.

A szintaktikai tudatosság esetén 26 mondatról, azaz 13 mondatpárról kellett megállípataniuk, hogy értelmes vagy értelmetlen, azaz grammatikailag hibás mondat hangzott-e el. A csoport átlaga ebben a feladatban 19,7 mondat (medián 20,5; szórás 4,6). Az életkori csoportok átlagai szerint az 5 évesek 14,7 mondatot ismertek fel, a 6 évesek 19,2 mondatot, a 7 évesek 21,3-at és a 8 évesek 23,9-et. Az egytényezős ANOVA-próba alapján kimutatható a különbség: $F(3,79)=$ 28,869; $p=0,000$. A Tukey-féle post hoc teszt az 5 és 6 , az 5 és 7 , valamint az 5 és 8 évesek csoportja között is erős, szignifikáns különbséget mutatott $(p<0,001)$, emellett a 6 és a 8 évesek csoportja között $(p<0,001)$ szintén erős szignifikáns különbség volt. Az életkori csoportokban a $80 \%$ feletti (21 vagy annál több helyesen felismert mondat) teljesítmény az 5 éves korosztálynál egyáltalán nem volt jellemző, a 6 évesek viszont nagy fejlődést mutatnak, hiszen 
itt a gyermekek 50\%-a (10 gyermek) teljesített a megadott teljesítményszint fölött, a 7 évesek 60\%-a (12 gyermek) érte el ezt az eredményt, a 8 éveseknél pedig 90\% (18 gyermek).

A szintaktikai tudatosság feladatban a kétnyelvü csoportok közül szintén a szimultán gyermekek teljesítménye volt jobb (lásd 2. ábra). Ebben az esetben a szukcesszív kétnyelvüséggel jellemezhető 5 évesek átlagban a mondatok 14,5\%-át ismerték fel, míg a szimultánok 14,9\%-át. A 6 éveseknél a szukcesszív csoport átlegeredménye $17,5 \%$, míg a szimultánoké $20,9 \%$. A 7 évesek esetében 20,7\%-ot teljesítettek a szukcesszív kétnyelvüek és 21,9\%-ot a szimultán kétnyelvűek, míg a 8 éveseknél az egynyelvü családból származó gyermekek eredménye 23,1\%-os lett, míg a vegyes családból származóké 24,8\%-os. A független mintás t-próba alapján a két csoport teljesítménye között statisztikailag nincs kimutatható különbség, csupán a százalékos adatok alapján látható a tendenciaszerü jobb teljesítmény a szimultán kétnyelvüségi csoportban.

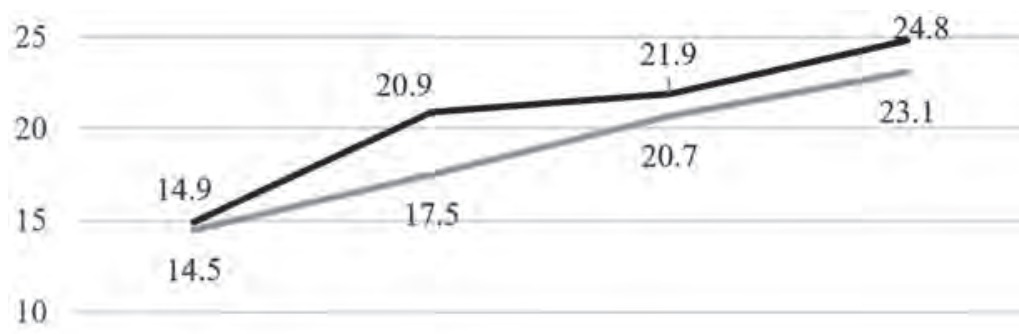

5

0

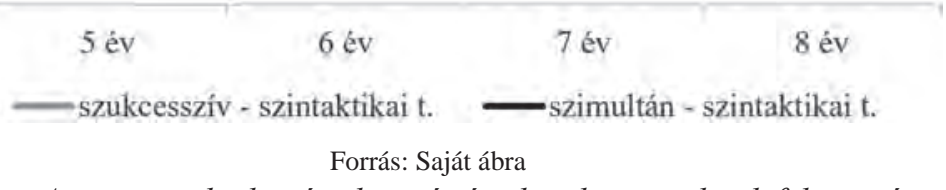

2. ábra. A grammatikailag értelmes és értelmetlen mondatok felismerése a kétnyelvüségi csoportokban életkori bontás szerint

A szintaktikai tudatosságot mérő tesztben is ellenőriztem a $80 \%$ fölötti teljesítményt a kétnyelvüségi csoportokban, ez 21 jól felismert mondatnak felel meg. Ezek alapján a szukcesszív csoportban az 5 évesek között nem volt ilyen magas teljesítmény, a 6 éveseknél a csoport 40\%-a (4 gyermek) mutatta ezt az eredményt, a 7 évesek esetében az arány $60 \%$-os (6 gyermek) volt és a 8 éveseknél 80\%-os (8 gyermek). A szimultán kétnyelvü gyermekek esetében a 5 évesek szintén nem tudtak $80 \%$ fölötti helyes válaszarányt produkálni, azonban 
a 6 éveseknél az arányok hirtelen magasra emelkedtek, így a csoport 60\%-a (6 gyermek) 26 mondatból legalább 21-et helyesen azonosított, a 7 éveseknél a százalékos arány szintén 60\%-os (6 gyermek), míg a 8 évesek (10 gyermek) mindannyian elérték a kívánt teljesítményhatárt.

A Moore-paradoxonos mondatok megértése és a szintaktikai tudatosságot mérő mondatok megértése között nemcsak a fejlődési ív hasonlóságát láthatjuk a százalékos számadatok alapján, hanem a Pearson-féle korrelációszámításból statisztikailag is kimutatható a két jelenség közötti összefüggés: $r=0,627, p<0,001$.

\section{Következtetés}

Az eredmények alapján megfogalmazható, hogy mind a Moore-paradoxonos mondatok felismerése, mind a szintaktikai tudatosságban a hibás és a helyes mondatok elkülönítése 7-8 éves kor körül alakul ki. A feltételezésem beigazolódott, hiszen a kétnyelvüségi csoportok közül a vegyes családban élő és szimultán kétnyelvüséggel jellemezhető gyermekek teljesítettek jobban, ezt az átlagok is megerősítik, és a $80 \%$ fölötti teljesítményben is ez a csoport mutatott jobb eredményeket. A Moore-paradoxonos mondatok felismerésére vonatkozó életkori átlagok összevethetőek magyarországi egynyelvű gyermekek eredményeivel. Ez alapján elmondható, hogy a kétnyelvủ gyermekek fejlődése hasonló az egynyelvüekéhez (vö. Kiss 2017), hiszen 5 évesen az egynyelvü gyermekek átlagosan 12, a kétnyelvủek 13,4 mondatot ismertek fel, a 8 évesek csoportja az egynyelvüeknél átlagosan 23 mondatot ismert fel, a kétnyelvűeknél ez az átlag 23,1.

A két csoport fejlődési dinamikáját megfigyelve az látható, hogy mindkét feladattípusban a szimultán csoportba tartozó gyermekek 5 és 6 éves kor között mutatnak ugrásszerü fejlődést, míg a szukcesszív kétnyelvüséggel jellemezhető csoportban a Moore-paradoxonok helyes felismerése 7 és 8 éves kor között válik stabillá, míg a szintaktikai tudatosság, kicsivel korábban, 6 és 7 éves kor között mutat jelentősebb fejlődést.

A tudatelméleti jelenségeket kétnyelvüek körében viszonylag kevés kutatás vizsgálja, magyar-román összefüggésben a Moore-paradoxonos mondatokkal kapcsolatos ilyen jellegü felmérés tudomásom szerint korábban nem készült. Ezek és tágabb értelemben a tudatelmélet fejlődésének vizsgálatai kétnyelvü közegben tovább bővíthetik az ismereteinket a kétnyelvüek sajátos kognitív müködéseiről, általuk megdőlhetnek a mai napig is létező kétnyelvüséggel kapcsolatos tévhitek, és az eredmények segíthetnek hatékonyan fejleszteni a vegyes környezetben élő gyermekeket, kihasználva azokat az előnyöket, amelyek az ö életükben a két vagy több nyelv ismerete által adottak. 


\section{Irodalom}

Adamikné Jászó Anna. 2006. Az olvasás múltja és jelene. Budapest: Trezor Kiadó.

Baron-Cohen, Simon-Swettenham, John. 1996. The relationship between SAM and ToMM: two hypotheses. In Theories about Theories of Mind, eds. Carruthers, PeterSmith, Peter K. 330-343. Cambridge: Cambridge University Press.

Bialystok, Ellen. 1991. Metalinguistic dimensions of bilingual language proficiency. In Language processing in bilingual children, ed. Bialystok, Ellen. 113-140. Cambridge: Cambridge University Press.

Bialystok, Ellen. 2006. Language and Literacy Development. In The Handbook of Bilingualism, eds. Bathia, Tej K.-Ritchie, William C. 577-603. Oxford: Blackwell Publishing.

Bialystok, Ellen. 2011. Coordination of executive functions in monolingual and bilingual children. Journal of Experimental Child Psychology 110. 461-468.

Bialystok, Ellen-Viswanathan, Mahesh. 2009. Components of executive control with advantages of bilingual children in two cultures. Cognition 112. 494-500.

Bialystok, Ellen-Feng, Xiaojia. 2009. Language proficiency and executive control in proactive interference: Evidence for monolingual and bilingual children and adults. Brain and Language 109. 93-100.

Carlson, Stepanie M.-Moses, Louis J. 2001. Individual Differences in Inhibitory Control and Children's Theory of Mind. Child Development 72 (4): 1032-1053.

Cromdal, Jakob. 1999. Childhood bilingualism and metalinguistic skills: Analysis and control in young Swedish-English bilinguals. Applied Psycholinguistics 20. 1-20.

Davidson, D.-Raschke, V. R.-Pervez, J. 2010. Syntactic awareness in young monolingual and bilingual (Urdu-English) children. Cognitive Development 25. 166-182.

Farrar, J. M.-Diaz, V. 2017. The missing explanation of the false-belief advantage in bilingual children: A longitudinal study. Developmental Science 1-14.

Fileva, I.-Brakel, L. A. W. 2018. Just another article on Moore's paradox, but we don't believe that. Synthese 1-15.

Francis, Norbert. 2002. Literacy, second language learning, and the development of metalinguistic awareness: A study of bilingual children's perception of focus on form. Linguistics and Education 13 (3): 373-404.

Galambos, Sylvia Joseph-Goldin-Meadow, Susan. 1990. The effects of learning two languages on level on metalinguistic awareness. Cognition 34. 1-56.

Galambos, Sylvia Joseph-Hakuta, Kenji. 1988. Subject-specific and task-specific characteristic of metalinguistic awareness in bilingual children. Applied Psycholinguistics 9. 141-162.

Green, Mitchell-Williams, John N. 2007. Introduction. In Green, Mitchell-Williams, John N. eds. Moore's Paradox. New Essays on Belief, Rationality, and the First Person. 3-36. Oxford: Clarendon Press. 
Heyes, Cecilia M. 1998. Theory of mind in nonprimates. The Behavioral and Brain Sciences (21): 101-114.

Kiss Szabolcs. 2015. A logika egyedfejlödése és szociológiája: Szemelvények a megismeréstudományok köréböl. Budapest: Könyvpont-L'Harmattan.

Kiss Szabolcs. 2017. Moore-paradoxonos mondatok felismerése gyermekkorban. In Bontakozó jelentés: Tanulmányok a 60 éves Péley Bernadette köszöntésére, szerk. Bóna Adrienn-Lénárd Katalin-Pohárnok Melinda. 111-119. Budapest: Oriold és Társai Kiadó.

Kovács, Á. M.-Téglás, E.-Endress, A. D. 2010. The Social Sense: Susceptibility to Others' Beliefs in Human Infants and Adults. Science 330 (6012): 1830-1834.

Premack, D.-Woodruff, G. 1978. Does the chimpanzee have a theory of mind? The Behavioral and Brain Sciences 4. 515-526.

Rosenthal, D. M. 1995. Moore's paradox and consciousness. Philosophical Perspectives 9, AI, Connectionism and Philosophical Psychology 313-333.

Searle, John R. 1983. Intentionality: An Essay in the Philosophy of Mind. Cambridge, UK: Cambridge University Press.

Searle, John R. 2009. Beszédaktusok: Nyelvfilozófiai tanulmány. Budapest: Alkalmazott Kommunikációtudományi Intézet-Gondolat Kiadó.

Török Tímea-Hódi Ágnes. 2015. A morfológiai tudatosság fejlődése, mérési lehetőségei és az olvasás-szövegértéssel való kapcsolata. Anyanyelv-pedagógia 1 . http:// www.anyanyelv-pedagogia.hu/cikkek.php?id=551. (2019. máj. 7.)

Wellman, Henry M.-Cross, David-Watson, Julanne. 2001. Meta-Analysis of Theoryof-Mind Development: The Truth about False Belief. Child Development 72 (3): 655-684.

Wellman, Henry. M.-Estes, David. 1986. Early understanding of mental entities: A reexamination of childhood realism. Child Development 57 (4): 910-923.

Wimmer, H.-Perner, J. 1983. Beliefs about beliefs: Representation and constraining functions of wrong beliefs in young children's understanding of deception. Cognition 13. 103-124.

\section{AGE-DIFFERENCES IN UNDERSTANDING MOORE-PARADOX SENTENCES BY BILINGUAL CHILDREN}

Bilingual children show better developed cognitive and executive functions than their monolingual peers. In my research I investigate the characteristics of understanding Moore-paradox sentences in bilingual children. In these sentences statements contain logically inconsistent propositions. My research aims to understand the development of this ability in bilingual children. My questions are: When do bilingual children develop the understanding of sentences containing logical inconsistency? Does 
the type of bilingualism affect the development of understanding? My experiment involved 80 simultaneous and successive bilingual children aged 5-8 years, whose task was to identify sentences containing the Moore-paradox. My results confirm that simultaneous bilingual children develop this ability faster than successive bilinguals. While the majority of the simultaneous group understands them at 5-6 years of age, the successive groups' understanding develops at the age of 7-8 years. Keywords: bilingualism, Moore's paradox, logical inconsistency, successive and simultaneous bilingualism

\section{UZRASTNE KARAKTERISTIKE U RAZUMEVANJU „MUR-PARADOKSALNIH REČENICA” KOD DVOJEZIČNE DECE}

Dvojezična deca pokazuju brojne prednosti u odnosu na jednojezičnu u pogledu kognitivnih i izvršnih funkcija. U radu se istražuju sposobnosti koje se povezuju sa razvojem teorije svesnosti kod dvojezične dece: tačnije, sa specifičnostima razumevanja „Mur-paradoksalnih rečenica”. Rezultati se upoređuju sa razvojem svesnosti u kompetenciji sintaksičkih konstrukcija. Cilj istraživanja jeste da se stekne uvid u karakteristike pomenutih sposobnosti kod dvojezične dece, te da se ustanovi vreme kada se te kompetencije javljaju, kao i da li su karakteristike i vreme pojavljivanja povezani. Pitanja na koje se u radu traže odgovori su: Kada se kod dvojezične dece javlja kompetencija razumevanja rečenica koje sadrže logičku protivurečnost? Da li tip dvojezičnosti utiče na kognitivni razvoj? Da li se može povući paralela između svesne sintaksičke kompetencije i između razumevanja „Mur-paradoksalnih rečenica”? U eksperimentu je učestvovalo 80 simultano i sukcesivno dvojezične dece uzrasta između 5 i 8 godina. Rezultati istraživanja potvrđuju da se simultano dvojezična deca brže razvijaju u odnosu na sukcesivno dvojezičnu.

Ključne reči: simultana i sukcesivna dvojezičnost, Mur-paradoks, sintaksička svesnost 